\title{
Efektivitas Latihan Rhytmic Stabilitation dan Combination Of Isotonic terhadap Penurunan Nyeri pada Nyeri Punggung Bawah
}

\author{
Yuliana Ratmawati $^{1^{*}}$, Yoni Rustiana Kusumawati ${ }^{2}$ \\ Poltekkes kemenkes Surakarta Jurusan Fisioterapi \\ *Email:juliafisio96@gmail.com
}

\begin{abstract}
Background: Low back pain is a complaint that is often encountered and very disturbing in carrying out daily activities. Myogenic pain is the most common complaint, around 49\%.Physiotherapy modalities that can be given are Proprioceptive Neuromuscular Facilitation (rhythmic stabilization and combination of isotonic). Purpose this study to analyze effectivity rhythmic stabilitation exercise and combination of isotonic to decreased pain for myogenic pain. Methods: this research is two groups pre and post test design. Subjects: 30 subject diagnosed with myogenic pain in Dr Moewardi Hospital during the period between 2019 June-Augs. Results: The result of test toward pain effect between pre and post in group one after 3 weeks (6 times of therapy) is $p=0.009$ with Wilcoxon test. The result of test toward pain between pre and post in group two is $p=0.001$ and the test of pain between group one and group two shows $p=0.051$. Conclusion: there is no difference in effect between the group one and group two toward the reduction of pain of patients with myogenic pain so that the results cannot be seen which is more effective.
\end{abstract}

Keyword: myogenic pain, proprioceptive neuromuscular facilitation

\section{PENDAHULUAN}

Nyeri Punggung Bawah (NPB) merupakan keluhan yang sering ditemui dan sangat mengganggu dalam melakukan aktifitas sehari-hari. Hampir 2 dari 3 individu pernah mengalami keluhan ini, minimal sekali dalam hidup mereka (Simms, 2001). Suatu survey di Amerika terhadap 3000 orang berumur 65 tahun ternyata $25 \%$ menderita nyeri punggung bawah. Akibat nyeri punggung bawah tersebut $40 \%$ terganggu aktifitas sehari hari dan $20 \%$ terganggu tidurnya. Secara keseluruhan $75 \%$ memerlukan perhatian medis dan sisanya $25 \%$ perlu dibawa ke rumah sakit (Cohen, et al 2001).

Pada negara maju prevelensi orang terkena NPB miogenik adalah sekitar 7080\%. Di Amerika kejadian NPB miogenik meningkat sebanyak $68 \%$ antara tahun1971-1981 (Bimaariotejo, 2009). Di Indonesia NPB miogenik dijumpai pada golongan usia 40 tahun. Secara keseluruhan, NPB miogenik merupakan keluhan yang paling banyak dijumpai sekitar 49\%. Ditinjau dari segi ekonomi, NPB banyak sekali membawa kerugian bagi penderita maupun negara oleh karena meningkatnya angka absensi ditempat dia bekerja dan biaya pengobatannya akan besar sekali.

NPB miogenik dapat ditimbulkan oleh beberapa faktor penyebab yaitu postur tubuh, kurang olahraga, berdiri atau membungkuk dalam waktu lama, duduk dengan kursi yang tidak egonomis, serta kegemukan (Bull and Archard, 2005). Gangguan yang terjadi akibat nyeri punggung bawah miogenik yaitu adanya nyeri tekan dari region lumbal, ketegangan otot yang menyebabkan spasme otot daerah lumbal. Bila keadaan ini berlanjut terus-menerus dalam waktu lama, akan menyebabkan kekuatan otot menurun, mobilitas gerak sendi lumbal menjadi terbatas sehingga dapat menimbulkan keterbatan saat bangun dari 
duduk, saat aktivitas memutar badan, saat duduk dan berdiri lama, serta saat berjalan mengalami gangguan (Borenstein dan Wiesel, 2004).

Intervensi fisioterapi terhadap NPB sangat bervariasi, terutama ditujukan untuk pengurangan nyeri, spasme, meningkatkan fleksibilitas dan stabilitas. Salah satu pendekatan intervensi fisioterapi pada NPB yang dapat diberikan dengan Proprioceptive Neuromuscular Facilitation (PNF) meliputi rhythmic stabilization dan combination of isotonic.

Penelitian dari Kofotolis (2006) menginformasikan perlakuan PNF (rhythmic stabilization dan combination of isotonic), berpengaruh terhadap daya tahan otot, fleksibilitas, dan fungsional yang dikarenakan adanya efek pengurangan nyeri. Teknik rhythmic stabilization menggunakan kontraksi isometrik dari kelompok agonis dan antagonis. Hal ini digunakan terutama untuk memperbaiki kondisi-kondisi kelemahan dan stabilisasi serta memberikan stimulasi pada pola agonis. Sedangkan teknik combination of isotonic adalah latihan PNF yang digunakan untuk mengevaluasi dan mengembangkan kemampuan untuk melakukan gerakan yang terkontrol, melibatkan kontraksi konsentrik, eksentrik, dan isometrik, yang berfungsi memperbaiki kelemahan otot dan lingkup gerak sendi (Alder et al, 2008).

Berdasarkan penelitian sebelumnya belum ada yang membandingkan kedua tehnik tersebut sehingga peneliti tertarik ingin mengetahui efektifitas latihan rhythmic stabilization dan combination of isotonic terhadap penurunan nyeri pada penderita nyeri pungung bawah miogenik

\section{METODE PENELITIAN}

Populasi penelitian ini adalah subyek yang mengalami nyeri punggung bawah miogenik pada periode bulan juliagustus di RSUD Moewardi Surakarta. Jenis penelitian ini adalah penelitian quasi eksperimental dengan menggunakan rancangan two group pre test - post test design.

Subyek penelitian yang memenuhi kriteria inklusi dan ekslusi dibagi menjadi dua kelompok, kelompok I diberi perlakuan rhythmic stabilization dan kelompok II diberi perlakuan combination of isotonic masing-masing sebanyak 6 kali, seminggu 2 kali selama 3 minggu. Sebelum diberikan perlakuan terlebih dahulu dilakukan pemeriksaan nyeri dengan Visual Analog Scale (VAS). dilakukan dengan cara pasien diminta untuk menunjukkan seberapa berat nyeri yang dirasakan pada garis horisontal sepanjang $100 \mathrm{~mm}$ kemudian subyek diminta menandai derajat nyeri yang dirasakan pada garis tersebut lalu pengambil data mengukur hasil derajat nyerinya. Pengukuran VAS dilakukan sebelum dan sesudah penelitian setelah 3 minggu perlakuan. Hasil data VAS sebelum dan sesudah perlakuan kemudian dianalisis. Untuk menentukan uji hipotesisnya dilakukan terlebih dahulu uji normalitas dengan Saphiro Wilk dan uji homogenitas. Uji hipotesis pre dan post kelompok I dan II menggunakan uji $t$ berpasangan bila data berdistriusi normal dan uji Wilcoxon bila data berdistribusi tidak normal. Uji hipotesis posttest kelompok I dan II menggunakan uji $\mathrm{t}$ tidak berpasangan bila syarat parametric terpenuhi dan uji Mann Whitney bila syarat parametric tidak terpenuhi.

Prosedur pelaksanaan rhythmic stabilization dilakukan dengan cara posisi 
pasien duduk di tepi tempat tidur menghadap terapis. Terapis meletakkan kedua tangannya tepat di tulang klavikula. Dari posisi tersebut, subyek diinstruksikan untuk gerak membungkuk sampai batas nyeri (dengan pola anterior depresi pada skapula) dan terapis memberikan tahanan. Tahanan perlahan-lahan meningkat sampai batas maksimal (posisi tersebut dipertahankan sekitar 5 detik) ,lutut terapis fleksibel mengikuti gerak tubuh pasien untuk menghindari cidera pada terapis itu sendiri. Kemudian tangan kanan terapis berpindah pegangan pada bahu bagian belakang (skapula) pasien sisi kiri, pasien diminta untuk menegakkan badan (mengekstensikan trunknya dengan pola posterior elevasi pada skapula), selanjutnya tangan kiri terapis megikuti berpindah pegangan ke pundak bagian belakang (skapula) kanan pasien untuk memberikan tahanan. Dosis latihan, setiap menyelesaikan 3 set, 15 repetisi dari masing-masing intervensi, istirahat 30 detik antara repetisi dan 60 detik antara set.

Combination of isotonic dilakukan dengan cara posisi pasien duduk di tepi tempat tidur menghadap terapis. Terapis meletakkan kedua tangannya tepat di tulang klavikula. Dari posisi tersebut, subyek diinstruksikan untuk gerak membungkuk sampai batas nyeri (fleksi trunk dengan pola anterior depresi pada skapula), terapis memberikan tahanan bertahap dari sangat lemah, lemah, sampai kuat (dari tahanan kuat posisi dipertahankan 5 detik), lutut terapis fleksibel mengikuti gerak tubuh pasien untuk menghindari cidera pada terapis itu sendiri. Melalui klavikula, terapis mendorong kembali agar pasien duduk tegak. Pasien secara perlahan menegakkan badannya (dengan melawan tahanan yang diberikan terapis). Kemudian tangan terapis berpindah pada skapula. Dari posisi tersebut, subyek diinstruksikan untuk gerak mengektensi trunk (dengan pola posterior elevasi pada skapula), terapis memberikan tahanan bertahap dari sangat lemah, lemah, sampai kuat (dari tahanan kuat posisi dipertahankan 5 detik). Melalui skapula, terapis menarik kembali agar pasien duduk tegak. Pasien secara parlahan menegakkan badannya (dengan melawan tahanan yang diberikan terapis). Dosis latihan setiap menyelesaikan 3 set, 15 repetisi dari masing - masing intervensi, istirahat 30 detik antara repetisi dan 60 detik antara set.

\section{HASIL PENELITIAN}

Karakteristik subyek berdasarkan umur berkisar pada rentang 30-60 tahun. Kelompok I terbanyak rata-rata usia 51-60 tahun, sedangkan kelompok II terbanyak rata-rata usia 41-50 tahun. 

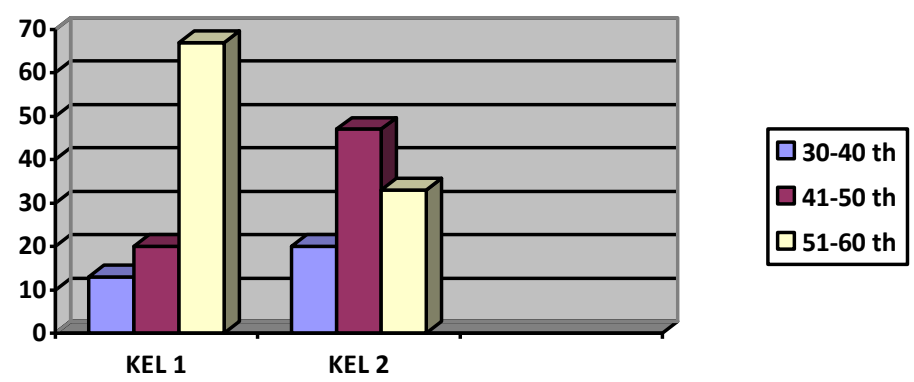

Gambar 1. Karakteristik Subyek Penelitian Berdasarkan Usia

Karakteristik subyek berdasarkan dikelompok II rata-rata berjenis kelamin jenis kelamin pada kelompok I rata-rata perempuan $67 \%$. berjenis kelamin laki-laki 53\% Sedangkan
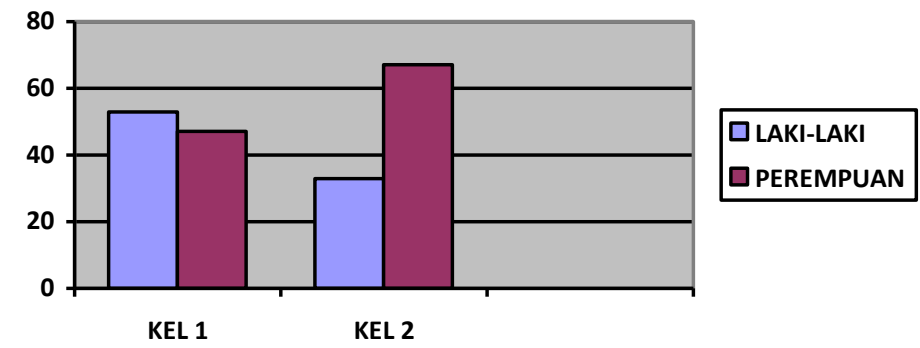

Gambar 2. Karakteristik Subyek Penelitian Berdasarkan Jenis Kelamin

Karakteristik subyek berdasarkan Sedangkan dikelompok II 60\% kategori Indeks Massa Tubuh (IMT) pada normal. kelompok I $60 \%$ kategori overweight.
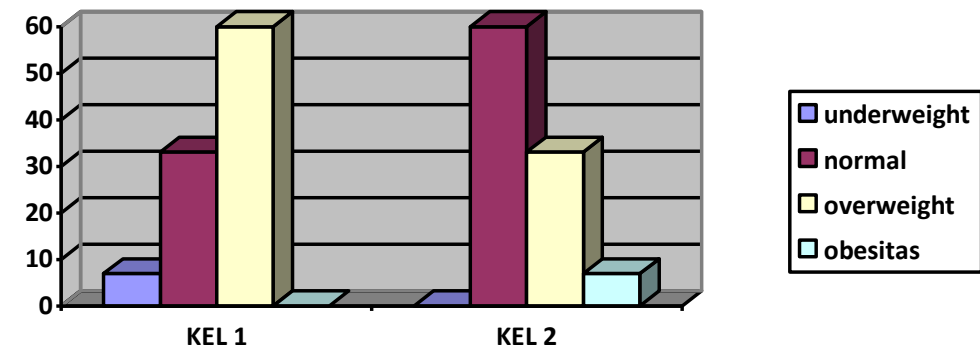

Gambar 3. Karakteristik Data Berdasarkan Indeks Massa Tubuh (IMT)

Karakteristik rata-rata VAS sebelum perlakuan 56 menjadi 52,8 nilai VAS dan sesudah perlakuan pada kelompok I Sedangkan dikelompok II dari sebelum mengalami penurunan dari sebelum perlakuan 49,2 menjadi 44,4 nilai VAS. 


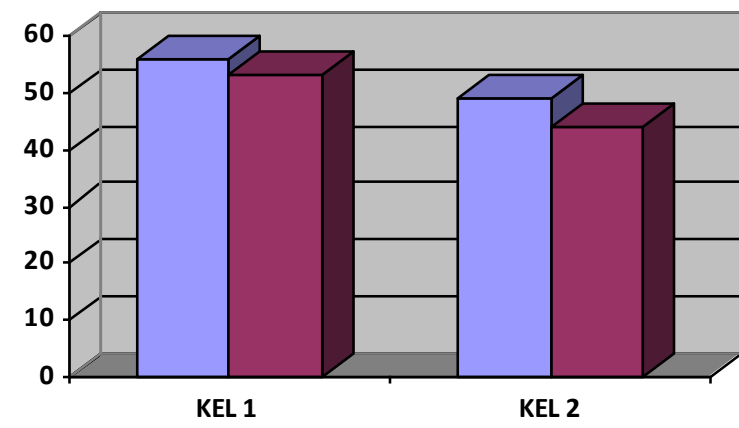

Gambar 4. Karakteristik rata-rata VAS sebelum dan sesudah Perlakuan

Hasil uji normalitas sebelum dan sesudah perlakuan menunjukkan nilai $\mathrm{p}<$ 0,05, maka data berdistribusi tidak normal. Sehingga untuk uji hipotesis menggunakan uji non parametrik. Sedangkan dari hasil uji homogenitas sebelum perlakuan didapatkan nilai $\mathrm{p}=0,881(\mathrm{p}>0,05)$ artinya data homogen. Karena data berdistribusi tidak normal maka uji hipotesis menggunakan uji non paramterik.

Tabel 1. Uji beda sebelum dan sesudah Perlakuan pada Kelompok I dan II

\begin{tabular}{cccc}
\hline VAS & N & $\boldsymbol{p}$ & Keterangan \\
\hline Kel I & 15 & 0,009 & Ada beda \\
Kel II & 15 & 0,001 & Ada beda \\
\hline
\end{tabular}

Sumber: data primer, 2019

Tabel 2. Uji beda sesudah Perlakuan antara kelompok I dan II

\begin{tabular}{cccc}
\hline VAS & N & $\boldsymbol{p}$ & Keterangan \\
\hline Post kel I & 15 & 0,051 & Tidak ada beda \\
Post Kel II & 15 & & \\
\hline
\end{tabular}

Sumber: data primer, 2019

\section{PEMBAHASAN}

Hasil penelitian ini menunjukkkan tidak ada perbedaan pengaruh antara pemberian rhythmic stabilization dan combination of isotonic terhadap penurunan nyeri. Hal ini sesuai dengan hasil penelitian dari Kofotolis (2006) dan Kumar (2011). Pemberian rhythmic stabilization berpengaruh terhadap penurunan nyeri pada pasien NPB miogenik, hal ini sesuai dengan penelitian yang dilakukan oleh Kofotolis (2006) yang menyatakan hasil bahwa rhythmic stabilization dapat meningkatkan fleksibilitas lumbal karena adanya efek penurunan nyeri. Menurut Kofotolis bahwa tehnik rhythmic stabilization merupakan kontraksi isometrik yang 
banyak digunakan pada pasien nyeri punggung bawah.

Teknik tersebut merupakan gerakan bergantian antara kelompok otot agonis dan antagonis tanpa diselingi periode relaksasi yang mengakibatkan reciprocal inhibition. Seperti diketahui salah satu faktor penghambat fleksibilitas adalah nyeri dan spasme. Dengan adanya penurunan nyeri dan spasme akibat rileksasi otot akan meningkatkan fleksibilitas lumbal (Kumar, 2011). Hal ini juga sesuai dengan penelitian Appleton (2003) menunjukkan kontraksi isometrik yang diberikan sebelum stretching dari otot yang mengalami ketegangan akan menghasilkan rileksasi sebagai hasil dari reciprocal inhibition. Adanya relaksasi akan meningkatkan lingkup gerak sendi.

Disisi lain kontraksi isometrik merupakan kontraksi statik yang akan mengaktivasi serabut saraf tipe II (A $\beta$ secondary receptors of muscle spindle). Adanya aktivasi pada serabut A beta akan menginhibisi neuron nosiseptif di kornu dorsalis medulla spinalis sehingga substansia gelatinosa menjadi aktif yang berdampak pada penurunan asupan terhadap sel $\mathrm{T}$ atau rangsang yang menuju pusat melalui sel $\mathrm{T}$ terhenti di mana serabut yang berdiameter besar (A beta) akan menutup gerbang dan membloking transmisi impuls dari serabut saraf aferen nosiseptor (Kuntono, 2011).

Pemberian combination of isotonic terhadap penurunan nyeri pada pasien NPB miogenik, hal ini sesuai dengan penelitian yang dilakukan oleh Kumar (2011), yang menunjukkan bahwa combination of isotonic dapat menurunkan nyeri dan spasme otot, sehingga terjadi peningkatan fleksibilitas lumbal. latihan isotonik otot berkontraksi melawan beban yang konstan dengan bagian tubuh bergerak melawan beban melewati sebuah lingkup gerak sendi. Peningkatan tonus otot akan merangsang golgi tendon organ serta memperbesar impuls saraf yang mencapai medulla spinalis. Terangsangnya golgi tendon organ otototot erektor spine akan mengaktifasi serabut saraf berpenampang tebal tipe $\mathrm{Ib}$ $(\mathrm{A} \alpha)$, aktivasi golgi tendon organ akan menghambat nosiseptor pada tingkat spinal, sehingga nyeri dan spasme dapat direduksi dan otot menjadi rileks (Foss, 2004).

Penelitian ini sesuai dengan penelitian Kofotolis (2006) yang menunjukan hasil bahwa combination of isotonic dapat meningkatkan fleksibilitas lumbal karena adanya penurunan nyeri. Secara teori combination of isotonic exercises akan mengaktivasi kontraksi isotonik otot-otot stabilisator punggung bawah sampai batas maksimal. Level endurance yang tinggi akan meningkatkan kemampuan otot-otot stabilisator punggung bawah dalam menjaga postur dan stabilitas punggung bawah sehingga pembebanan pada struktur lumbal dapat diminimalkan. Latihan isotonik meningkatkan ketegangan yang akan merangsang golgi tendon organ otot-otot erektor spine. Sinyal dari golgi tendon organs dihantarkan ke medula spinalis untuk menimbulkan efek refleks pada otot yang bersangkutan. Efek inhibisi dari golgi tendon organs menyebabkan rileksasi seluruh otot secara tiba-tiba. Istilah lain untuk efek inhibisi adalah autogenic inhibition atau juga inverse myotatic reflex. Efek inhibisi terjadi pada waktu kontraksi atau regangan yang kuat pada suatu tendon. Keadaan ini menyebabkan suatu refleks seketika yang menghambat kontraksi otot serta tegangan 
dengan cepat berkurang. Pengurangan tegangan ini berfungsi sebagai suatu mekanisme protektif untuk mencegah terjadinya robek pada otot atau lepasnya tendo dari perlekatannya ke tulang. Hal ini hanya mungkin diciptakan oleh impulsimpuls golgi tendon organs yang berfungsi sebagai pencegah yang menolak pembangkitan impuls-impuls dari muscle spindle (Juliantine, 2010)

Hasil penelitian ini menunjukkkan tidak ada perbedaan pengaruh antara pemberian rhythmic stabilization dan combination of isotonic terhadap penurunan nyeri. Karena tidak ada perbedaan pengaruh antara kedua kelompok sehingga dari hasil tersebut tidak dapat dilihat mana yang lebih efektif. Beberapa faktor yang menyebabkan tidak ada perbedaan pengaruh antara pemberian rhythmic stabilization dan combination of isotonic adalah penelitan ini hanya menggunakan subyek sejumlah 15 pada masing-masing kelompok, dan variabel penggganggu yang tidak semua bisa dikendalikan seperti aktivitas. Sedangkan pada penelitian Kofotolis (2006) menggunakan subyek sejumlah 86, dan variabel pengganggu yang dapat dikendalikan. Selain itu pada kedua tehnik tersebut mempunyai manfaat yang sama yaitu sama-sama dapat mengurangi nyeri, dan menimbulkan rileksasi pada otot penderita NPB miogenik kronis.

\section{KESIMPULAN DAN SARAN}

Subyek pada penelitian ini adalah penderita nyeri punggung bawah myogenic di RSUD Dr Moewardi Surakarta. Subyek yang diberikan latihan rhythmic stabilization dan combination of isotonic terhadap penurunan nyeri tidak menunjukkan adanya perbedaan diantara keduanya, sehingga dari hasil tersebut tidak bisa dilihat mana yang lebih efektif. Akan tetapi dari melihat hasil selisih mean setelah perlakuan antara kedua kelompok, kelompok yang diberikan perlakuan latihan rhythmic stabilization menunjukkan selisih mean lebih kecil daripada kelompok yang diberikan perlakuan latihan combination of isotonic. Adapun perbedaan nilai selisih mean tersebut tidak menunjukkan perbedaan yang berarti. Rhythmic stabilization dan combination of isotonic masing-masing sebanyak 6 kali, seminggu 2 kali selama 3 minggu.

Dari hasil analisis data dapat disimpulkan tidak terdapat perbedaan pengaruh antara latihan rhythmic stabilization dan combination of isotonic terhadap penurunan nyeri pada penderita nyeri punggung bawah miogenik sehingga penelitian ini dapat menjadi referensi fisioterapis dalam menangani nyeri punggung bawah dengan memilih antara latihan rhythmic stabilization atau combination of isotonic karena keduanya dapat mengurangi nyeri pada nyeri punggung bawah miogenik.

Saran pada penelitian selanjutnya adalah (1) perlu dilakukannya kontrol aktifitas pada subyek penelitian, (2) perlu subyek yang lebih banyak dan adanya randomisasi pada subyek penelitian.

Terima kasih kami ucapkan kepada semua yang terlibat pada penelitian ini ,pasien di RSUD Dr Moewardi Surakarta khususnya pasien nyeri punggung bawah miogenik di Poli Fisioterapi RSUD Dr Moewardi.

\section{DAFTAR RUJUKAN}

Alder, S., Beckers, D., and Buck, M. (2008). PNF in Practice ; Thrid Edition, Philadelphia. 
Appleton, B.D. (2003). Strecth and flexibility; Buletin Sport Injury `http://www.enteract.com/ bradapp/ docs/rec/stretching/'

Bimaariotejo, H. (2009). Low Bak Pain; diakses tanggal 10112011 dari $\mathrm{http}$ :bimaariotejowordpressos=lbp

Borestein, dan Wissel. (2004). Low back pain Medical diagnosis and comprehensive management; $\mathrm{WB}$ Saunders Company, Philadelphia, hal. 147- 169.

Bull, E., dan Archad, G. (2005). Nyeri Pinggang; Erlangga,Jakarta

Cohen, R., (2001). Low Back Pain part I, primary work-up of acute and cronics symtomps Geriatrics hal 5967

Foss, M.L., \& Marin, H.N. (2004). Effect of Submaximal Contraction Intensity in Contract Relax Propioseptif Muscular Facilitation Stretching; Retrieved April, 17, 2010, from www. Bjsportmed.com

Juliantine T. (2010). Studi Perbandingan Berbagai Macam Metode Latihan Peregangan Dalam Meningkatkan Kelentukan. Universitas Pendidikan Indonesia.

Kofotolis, N., Kellis, E. (2006). Effects of Two 4-Week Proprioceptive Neuromuscular Facilitation Programson Muscle Endurance, Flexibility, and Functional Performance in Women With Chronic Low Back Pain; Retreived
September, 3, 2011, from http://ptjournal.apta.org.

Kumar, A., And Zutshi, K. (2011). Efficacy ?of Trunk Proprioceptive Neuromuscular Facilitation Training on Chronic Low Back Pain; May, 2011

Kuntono, H.P. (2011). Nyeri Secara Umum dan Osteoarthritis Lutut dan Aspek Fisioterapi; Muhammadiyah University Press, Surakarta. Hal 1, $1-2$

Simms R.W. (2001). Low Back Pain in Field Guide To Soft Tissue Pain, Lippinkott W\&W, Philadelphia 